\title{
Opportunities of Organizational Communication at Regional Leadership Council (DPD) I Hizbut-Tahrir Indonesia, North Sumatra in
}

\author{
Kamaludin ${ }^{1}$ \\ ${ }^{1}$ Ph.D Student at Islamic Communication Program, Postgraduate Program, State Islamic University, UINSU, \\ Medan, Indonesia \\ ${ }^{I}$ Head of KUA, Kecamatan Lubuk Pakam, Kabupaten Deliserdang
}

\begin{abstract}
Some Islamic Political Parties and some of political party based on Islam in Indonesia support democracy and choose democratic system as the best solution solving life of the nation. Some Islamic Political Parties and some of political party based on Islam in Indonesia believe that the democratic system is in accordance with the teachings of Islam. Meanwhile, Hizbut-Tahrir Indonesia is strongly opposed to the democratic system and looks at this system as a kufr system. Hizbut-Tahrir Indonesia North Sumatra has a formidable cadre/members. This organization also has a good management organization and management da'wah. Having a strong faith for the success of da'wah. Da'wah message conveyed by Hizbut-Tahrir is a universal message of kindness which are not for one class only. Have a clear concept of the caliphate.
\end{abstract}

Keywords: organizational organization; Hizbut Tahrir; political parties; khilafah

\section{INTRODUCTION}

Hizbut-Tahrir Indonesia continues to spread the idea of anti-democracy and anti-nationalism. Democracy by Hizb ut-Tahrir Indonesia, is unlawful and incompatible with the Islamic system. Nationalism is the product of the invaders and it is ashobiah behavior which is contrary to the teachings of Islam. Da'wah communication messages by Hizbut Tahrir Indonesia is something that is considered daring, amid the current global power which is intensively campaigning for democracy. Though Indonesia as a country with a majority Muslim but the country is trying to become a democratic state, after several years led by an authoritarian regime.Communication message conveyed is clearly contrast and it is very controversial. Some Islamic Political Parties and some of political party based on Islam in Indonesia support democracy and choose democratic system as the best solution solving life of the nation. Some Islamic Political Parties and some of political party based on Islam in Indonesia believe that the democratic system is in accordance with the teachings of Islam. Meanwhile, Hizbut-Tahrir Indonesia is strongly opposed to the democratic system and looks at this system as a kufr system. Besides, Hizbut Tahrir is firmly opposed to ideological concepts which have been well known as capitalism, communism, secularism, pluralism and nationalism.Hizbut-Tahrir has attracted the attention of Muslims, particularly young people who look at that thought brought by Hizbut Tahrir is something new. The development of this organization is truly extraordinary, estimated currently has ten thousands of cadres and millions of sympathizers throughout Indonesia. In North Sumatra, Hizbut Tahrir is currently estimated to have hundreds thousands of cadres and sympathizers.Regional Leadership Council (DPD) I of Hizbut-Tahrir Indonesia, North Sumatra, is as a part of Hizbut-Tahrir organization. What is the purpose of the Hizbut Tahrir as mentioned above is also a goal that will be realized by Regional Leadership Council (DPD) I of HizbutTahrir Indonesia, North Sumatra. What is the vision and mission of the Hizbut Tahrir is also the vision and mission of the Regional Leadership Council (DPD) of Hizbut-Tahrir Indonesia, North Sumatra.

\section{METHODOLOGY}

\subsection{Definition of Organizational Communication}

Organizational communication is a combination of two words, namely communication and organization. To be able to give a full understanding of the organization's communication, we must understand the meaning of communication and organization. The term of communication comes from Latin, meaning communicatus shared or jointly owned. In adjective its meaning is communis means public or together. Thus communications under lexicographer (expert dictionary), refers to a measure aimed shared to achieve unity.In terms, many experts give a definition of communication based on their viewpoint. Such as William Albig in his book Public Opinion and quoted by Latif Rousdy (2005) states that "comunication is the process of transmitting meaningful symbols between individuals". Meaning: communication is the process of transfer of symbols 
among individuals. Warren Weaver defines communication as a whole procedure by which a mind influenced the minds of other.Definition of communication described above is still simple, because communication is not just a purely informative nature that people understand and know it can also be persuasive, namely that other people are willing to receive a notion or belief or perform an action or activity and others. Because of it, a sociologist, psychologist and political scientist named Carl I. Hovlan as quoted by Onong Uchjana (2001) defines communication that systematic effort to formulate rigid principles of information delivery as well as the formation of opinions and attitudes. Definition puts forward by Carl I. Hovlan above showing that communication is not just the delivery of information, but also the formation of public opinion and public attitudes who live and social and political life plays an important role.

Some experts define many definition of organizations including:

a. Chester I. Barnard said that organization as a system of cooperative of two or more persons who have the same vision and the same mission.

b. Dimock, defines organization is a blend rather than parts interdependence relates to form a unity round through coordination and supervisory authority in order to achieve a predetermined goal. While Deddy Mulyana (2005) defines organizational communication is the communication that occurs in an organization, formal and informal and takes place in a bigger network than the group communication. Formal communication is communication according to the organizational structure, the downward communication, upward communication and horizontal communication. While informal communication does not depend on the organizational structure.

The method used in this research is descriptive qualitative. Bogdan and Biklen (1982) in Kholil (2006) define qualitative research as research produced data descriptive form of words written or spoken of people and behaviors that can be observed. Qualitative research is often called the study of natural and there are those who call it a case study. Design research is temporary and can be changed when there are developments that enable qualitative changes. Qualitative research is chosen based on the consideration that;

1) The problem under study requires a disclosure that is descriptive and comprehensive;

2) The qualitative approach is more sensitive and able to adjust when used to examine the various influences and patterns of respondents value encountered under natural conditions;

3) The qualitative data capable of revealing the events chronologically, evaluate causality, are able to find something that is not unexpected, and able to provide an explanation that many and beneficial to build a new theoretical framework;

4) 4) The findings of qualitative research can give the impression that is more real, more alive and full of meaning, so it is more convincing and acceptable. An early indication of the qualitative study is that the data or information collected over the form of words rather than numbers. This indication appears, when all the information gathered about the reality or phenomena arranged in the form of verbal descriptions or words.

In this study, the data is obtained through field research. The data used in this study are primary data and secondary data. Data form of observation/direct observation research on the object of research and interviews. Average secondary data documentation studies and books on how to read, understand and analyze the documents and literature related to the discussion of this research. Primary data form of observation/direct observation research on the object of research and interviews of researchers at competent sources, including: a. observation which is done by participating (participant observation) in each of the activities of Hizbut-Tahrir and interact directly with the activists of Hizbut-Tahrir Indonesia. Focus direct observations are made by observing the activities of the activists of Hizbut-Tahrir Indonesia North Sumatra and the core committee of Hizbut Tahrir North Sumatra in Medan and Deli Serdang.b. Interview. Interviews are conducted with a number of officials and activists of Hizbut Tahrir focus on observation, namely:

1) Irwan Said Batubara, Head of DPD I Hizbut Tahrir Indonesia Sumatera Utara.

2) Syaiful Rahman S.Hi, Secretary of DPD I Hizbut Tahrir Indonesia Sumatera Utara.

3) Muhammad Amin al-Fatih, Head of Lajnah Tsaqofiyah DPD I Hizbut Tahrir Indonesia Sumatera Utara.

4) Muhammad Yusran, ketua Lajnah Mashlahiyah DPD I Hizbut Tahrir Indonesia Sumatera Utara.

5) Muhammad Basyuni, ketua Lajnah Intelektual DPD I Hizbut Tahrir Indonesia Sumatera Utara.

6) Marwan Rangkuti, a former spokesman in communication and information duty at DPD I Hizbut Tahrir Indonesia Sumatera Utara.

\section{DISCUSSION}

Organizational communication conducted by Regional Leadership Council (DPD) I Hizbut-Tahrir Indonesia North Sumatra has a tremendous opportunity in order to achieve the vision and mission of the organization and the purpose of the organization in da'wah of DPD I Hizbut Tahrir, namely: 


\section{1) Having a formidable cadre}

Regional Leadership Council (DPD) I Hizbut-Tahrir Indonesia North Sumatra has a formidable cadre/members. Hizb members are those who have fostered intensive at-tsaqafah al-murakkazah) to individuals and development in society in general. Through group studies (halqah) individuals forms with the Islamic personality and intended to carry out da'wah. With intensive coaching, Hizbut members have embraced fikrah (thinking) and thariqah Hizbut-Tahrir (Hizb method). Prospective members of Hizbut-Tahrir (daris) led in following halqah by reviewing three pieces of books: Nidzam Al-Islam, at-takattul al-hizbi, Mafahin Hizb atTahrir and Min Muqowwimat an-Nafsiyyah al-Islamiyah.

\section{2) Having good organization management and da'wah management}

Regional Leadership Council (DPD) I Hizbut-Tahrir Indonesia North Sumatra as a portion of the Hizb International has a good organization management and da'wah management. Regional Leadership Council (DPD) I Propagation Hizbut-Tahrir Indonesia North Sumatra as a da'wah organization has implemented the principles of organizational management and management of da'wah proselytizing. Vision, mission and goals of the organization is clear and understood by every member of the organization. Da'wah performed by DPD Hizbut-Tahrir Indonesia is not done suddenly but through advance planning. DPD Hizbut-Tahrir Indonesia North Sumatra has da'wah roadmap as a guideline/guidelines for all members of Hizb. Da'wah planning is implemented and evaluated continuously.

\section{3)Having a strong faith}

Confidence is the main capital for the change. Each member of Hizbut-Tahrir has a strong belief that da'wah they do will be successful, because it is the promise of Allah through His Prophet, Muhammad SAW. There is a hadith of the Prophet that they believe to be true that there will be born a time, the system of government like the system created by the Prophet Muhammad SAW.

4) universal message. Propaganda message conveyed by Hizb ut-Tahrir is a universal message of kindness which are not for one class only. Islamic Shari'ah which becomes the central theme of da'wah is teaching as a mercy to all the worlds without exception. According to Hizb, good message should be delivered in a good way too.

\section{A clear concept of caliphate}

Said Irwan Batubara, Chairman of DPD I Hizbut-Tahrir Indonesia North Sumatra claims that Hizb is the first organization that carries the theme of caliphate. The concept of the caliphate carried by Hizbut-Tahrir is a mature concept and ready to run. Hizb is ready when given the power to carry out the concept of caliphate based on Islamic law, not just the expression or simply jargon.

\section{Decaying capitalist system, communism and democracy}

Decaying system today adopted by the nations in the world as the capitalist system, communism and democracy is a distinctive opportunity for doing da'wah by Hizb. Nowadays people have witnessed and felt the depravity of man-made system that is the capitalist system, communism and democracy, only the people have not been introduced by the Islamic system that is khilafah.

\section{7) Advances in Information Technology}

Technologically, progress information is an opportunity for da'wah by Hizbut-Tahrir. DPD HizbutTahrir Indonesia North Sumatra uses internet to call people. DPD Hizbut-Tahrir Indonesia North Sumatra has a website, facebook, twitter, WA, and cyber team. By utilizing the internet, the ideas of Hizb is easier to be conveyed.

\section{CONCLUSION}

The opportunity of organizational communication Regional Council (DPD) I Hizbut-Tahrir Indonesia North Sumatra in the development of organization and da'wah, namely, the Regional Leadership Council (DPD) I Hizbut-Tahrir Indonesia North Sumatra has a formidable cadre/members. This organization also has a good management organization and management da'wah. Having a strong faith for the success of da'wah. Da'wah message conveyed by Hizbut-Tahrir is a universal message of kindness which are not for one class only. Have a clear concept of the caliphate. This organization uses internet to preach through websites, facebook, twitter, WA, and cyber team. 


\section{REFERENCES}

[1] al-Qur'an al-Karim dan Terjemahnya. Riyadh, Arab Saudi, Kementerian Agama dan Wakaf, 1998. Abdullah, Kurniawan "Gerakan Politik Islam Ekstraparlementer: Studi Kasus Hizbut Tahrí Indonesia", Tesis, UI, tidak dipublikasikan, 2003.

[2] al-Bayanuni, Muhammad Abu al-Fath. al-Madkhal ila 'Ilm al-Dakwah, Beirut: Muassasah al-Risalah, 1993.

[3]

Nasyirun, 2001. Al-Madkhal Ila 'Ilmi Al-Da'wah, Beirut: Muassah Al-Risalah

[4] al-Faris, Ibnu. Mu'jam Maqayisil Lughah, tt: t.p.t.th.al-Jurjani, Ali M.Syarif. At-Ta'rifat, Beirut: Dảrun Nafä'is. 2003.

[5] al-Ishfahany, Raghib. al-Mufradhat fi Gharibil Quran, Mesir: Musthafa Baby al-Halaby wa Auladuh, 1961.

[6] al-Manzhur, Ibnu. Lisan Al- 'Arab, Kairo: Dar Al-Ma'arif, tt.al-Nabhani, Taqiyyudin. Membangun Sistem Ekonomi Alternatif Perspektif Islam, Terj. Nurkhalish, Surabaya: Risalah Gusti, 1996.

[7] al-Sabuni, Muhammad, Ali. Tafsīr al-Sābūnī. Beirut: Dar al-Hadis, 1998.Aziz, Moh. Ali. Ilmu Dakwah, Jakarta: Kencana Prenada Media Group, 2009.

[8] Batubara, Abdul Karim. Dakwah di Era Cyber, dalam Syahrul dan Rubino (Ed). Dinamika Dakwah, Bandung: Citapustaka Media, 2010.

[9] Bertens, K. Metode Belajar Untuk Mahasiswa, Jakarta: Gramedia Pustaka Utama, 2005.Departemen Pendidikan dan Kebudayaan, Kamus Besar Bahasa Indonesia, Jakarta: Balai Pustaka, 1984.

[10] Dirdjosisworo, Soerjono. Asas-asas sosiologi, Bandung: Armico, 1985.

[11] Echols, John. M. dan Hasan Shadily, Kamus Inggris Indonesia, Jakarta: Gramedia, 2000.Effendy, Onong Uchjana. Komunikasi Teori dan Praktek, Bandung: Remaja Rosdakarya, 2001.

[12] Fajar, Marhaeni. Ilmu Komunikasi Teori \& Praktek, Yogyakarta: Graha ilmu, 2009.Foss, Stephen W. Litlle John dan Karen A. Teori Komunikasi ,Terj. Muhammad Yusuf Hamdan, Jakata: Salemba Humanika, 2013.

[13] Gaspersz, V. Sistem Manajemen Kinerja Terintegrasi Balanced Scorecard dengan Six Sigma untuk Organisasi Bisnis dan Pemerintah, Jakarta: PT Gramedia Pustaka Utama, 2003.

[14] Hamka, Rusydi. Islam dan Era Informasi, Jakarta: Pustaka Panjimas, 1989.Hasmy, A. Dustur Dakwah Menurut Al-Quran, Jakarta: Bulan Bintang, 1997.

[15] Hasibuan. Manajemen Sumber Daya Manusia. Jakarta: Bumi Aksara, 2002.Hadari, Nawawi. Managemen Sumber Daya Manusia, Yokyakarta: Gajah Mada University Press, 2000.

[16] Hizbut Tahrir, Titik Tolak Perjalanan Dakwah Hizbut Tahrir. terj. Muhammad Maghfur, Bogor: Pustaka Thariqul Izzah, 2000.

[17] Hizbut Tahrir, Strategi Dakwah Hizbut Tahrir, terj. Abu Fuad dan Abu Raihan, Bogor: Pustaka Thariqul Izzah, 2000.

[18] Huberman, Matthew. B Miles \& Michael. Analisis data Kualitatif, Terj. Tjetjep Rohendi Rohidi, Jakarta: UI Press, 1992.

[19] Jamil, Abdullah. Wawasan Dakwah Kajian Epistemologi, Konsepsi dan Aplikasi Dakwah, Medan: IAINPress, 2001.

[20] Johannesen, Richard L. Ethics in Human Communcation (Terj) Dedy Djamaluddin Malik dan Deddy Mulyana, Bandung: Rosdakarya, 1996.

[21] John, Sthepen W. Litlle. Theories Of Human Communication, USA: Thomson Learning, 2001.Kertapati, Ton. Dasar-dasar Publisistik, Jakarta: Bina Aksara, 1981.

[22] Kholil, Syukur. Metodologi Penelitian Komunikasi, Bandung: Cita Pustaka Media, 2006.Liliweri, Alo. Wacana Komunikasi Organisasi, Bandung: Mandar Maju, 2004.

[23] Ma'luf, Luwis. Qamus al-Munjid, Beirut: Al-Maktabah Al-Khathulikiyah, 1951.Mangkunegara, Prabu Anwar. Perilaku Dan Budaya Organisasi, Bandung: Penerbit Refika Aditama. 2000.

[24] Masmuh, Abdullah. Komunikasi Organisasi Dalam Perspektif Teori dan Praktek, Malang: UMM Press, 2008.

[25] Mardiasmo. Akuntansi Sektor Publik, Yogyakarta: Andi, 2004.Matondang, Ali Yakub. Tantangan Dakwah Dalam Era Globalisasi, dalam An-Nadwah, Vol. 4.

[26] McGill, Michael E. Pengembangan Organisasi, Terj. Rochmulyati Hamzah, Jakarta: PT. Jaya Pirusa, 1982.

[27] Moleong, Lexi J. Metodologi Penelitian Kualitatif, Bandung: PT. Remaja Rosdakarya, 2001.Muhammad, Hasyim. Dialog antara Tasawuf dan Psykologi, Yokyakarta: Pustaka Pelajar, 2002.

[28] Mulyana, Deddy. Ilmu Komunikasi suatu Pengantar, Bandung: Remaja Rosdakarya, 2005.Mulyadi dan Johny Setyawan. Sistem perencanaan dan Pengendalian Manajemen, edisi kesatu, Yogyakarta: Aditya Media, 1999. 
[29] Mulyadi. Balanced Scorecard: Alat Manajemen Kontemprer untuk Pelipat ganda Kinerja Keuangan Perusahaan, Jakarta: Salemba Empat, 2001.

[30] Mustafa, Ali. Membangun Dakwah Humanis di Era Globalisasi, dalam Muhammad Habibi Siregar dan Joko Susanto, Dakwah Humanis, Bandung: Citapustaka Media, 2014

[31] Nawawi, Hadari. Managemen Sumber Daya Manusia, Yokyakarta: Gajah Mada University Press, 2000.

[32] Nasution, S. Metode Penelitian Naturalistik Kualitatif, Bandung: Tarsito,1988.Novitayani, Amita. Iklim Komunikasi Organisasi, Motivasi Kerja Karyawan (Studi Korelasi Antara Iklim Komunikasi Organisasi, Motivasi Kerja dengan Pretasi Kerja di Kalangan Karyawan AJB. Bumiputra Solo), Surakarta: Universitas Sebelas Maret Surakarta, 2008.

[33] Oemar, Toha Yahya. Ilmu dakwah, Jakarta: Wijaya, 1976.Pace R. Wayne dan Don F. Faules. Komunikasi Organisasi Strategi Meningkatkan Kinerja Karyawan, Terj. Deddy Mulyana: Bandung Remaja Rosdakarya, 2005.

[34] Rahmat, Jalaluddin. Islam. Islam Aktual, Bandung: Mizan, 1996.Rais, Amin. Cakrawala Islam, Bandung: Mizan, 1991.

[35] Rivai, Veithzal dkk, Pemimpin dan Kepemimpinan Dalam Organisasi, Jakarta: Raja Grafindo Persada, 2014.

[36] Robbin, Stephen P. Prilaku Organisasi, Jakarta: Salemba Empat, 2015.Robbin, Stephen P. Teori Organisasi, struktur desains dan Aplikasi, Terj. Udaya Yusuf, Jakara: Arcan, 1994.

[37] Rodhi, Muhammad Muhsin. Tsaqofah dan Metode Hizbut Tahrir dalam Mendirikan Negara Khilafah, Terj. Muhammad Bajuri dan Romli Abu Wafa, Bogor: al-Azhar Fresh Zone Publishing, 2012.Rousdy, Latief. Dasar-dasar Rethorika Komunikasi dan Informasi, Medan: FA Rimbow, 1985.

[38] Samarah, Ihsan Biografi Singkat Taqiyuddin al-Nabhani, Bogor: Al-Izzah Press, 2002.Senjaya, Djuarsa. Teori Komunikasi, Jakarta: Universitas Terbuka, 2002.

[39] Silalahi, S. Studi Tentang Ilmu Administrasi, Konsep, Teori dan Dimensi, Bandung: Sinar Baru Algensindo, 2002.

[40] Simamora. Manajemen Sumber Daya Manusia, Yogyakarta: STIE YPKN, 1993.Syamsuri, Hamzah. Kamus Lengkap bahasa Indonesia, Surabaya: Greisinda, tt.

[41] Syarifuddin, Amir. Ushul Fiqh Jilid I, Ciputat, Logos Wacana Ilmu: 1997.Syihab, Quraish. Tafsir alMishbah, Jakarta: Lantera Hati, 2002.

[42] Sukanto, Soeryono. Sosiologi suatu pengantar, Jakarta: Raja Grafindo Persada, 2002.Tahir, Arifin. Buku Ajar Prilaku Organisasi, Yokyakarta: Deepublish, 2014.

[43] Tantowi. Unsur-Unsur Manajemen Menurut Al-Qur'an, Jakarta: Pustaka Al -Hasan, 1983.Team Penyusun Kementerian Agama RI, Tafsir Alqur'an Tematik, Jakarta: Lajnah Pentashihan Mushaf alQur'an Kementerian Agama Republik Indonesia, 2012.

[44] Thoha, Miptah. Perilaku Organisasi Konsep Dasar dan Aplikasinya, Jakarta: Raja Grafindo Persada, 2013

[45] Turner, Richard West dan Lynn H. Introducing Communication Theori Analysis and Application, New York: McGraw-Hill, 2007.

[46] Umam, Khaerul. Manajemen Organisasi, Bandung: Pustaka Setia, 2012.Wahjosumidjo. Kepemimpinan Kepala Sekolah, Tinjauan Teoritik dan Permasalahaannya, Jakarta: PT. Raja Grafindo Persada, 2001.

[47] www.hizbut-tahrir.or.id, diakses, 8 Juni 2014. 